\title{
Sanitary and Physiological Quality of Soybean Seeds Treated With Ozone
}

\author{
Vitor O. Rodrigues ${ }^{1}$, Amanda C. Penido ${ }^{1}$, Diego de S. Pereira ${ }^{1}$, Ariadne M. S. Oliveira ${ }^{1}$, Alan Eduardo S. Mendes ${ }^{1}$ \\ \& João Almir Oliveira ${ }^{1}$ \\ ${ }^{1}$ Universidade Federal de Lavras, Lavras, Brazil \\ Correspondence: Amanda C. Penido, Universidade Federal de Lavras, Lavras, Campus Universitário, Brazil. Tel: \\ 55-359-9822-1975. E-mail: apenidoufla@gmail.com
}

$\begin{array}{ll}\text { Received: November 25, } 2018 & \text { Accepted: January 19, } 2019 \quad \text { Online Published: March 15, } 2019 \\ \text { doi:10.5539/jas.v11n4p183 } & \text { URL: https://doi.org/10.5539/jas.v11n4p183 }\end{array}$

\begin{abstract}
Widely used, the seeds chemical treatment can cause physiological quality loss due to phytotoxicity that the active principles may cause. In this context, the ozone gas stands out $\left(\mathrm{O}_{3}\right)$ as efficient agent biocide, however its use in the pathogens control and their effects on the seeds physiological quality are still little studied. In this context, the objective was to evaluate the ozone gas efficiency as a controller agent of plant pathogens and its effect on the physiological quality of soybean seeds. For this, seeds of two soybean cultivars were treated with ozone gas in two concentrations $\left(15\right.$ and $\left.25 \mathrm{~g} / \mathrm{m}^{3}\right)$ and in five exposure times $(0,20,40,60$ and 120 minutes). After the treatments, the seeds quality was evaluated by tests of sanity, tetrazolium, first germination count, germination percentage, initial stand, emergence percentage, emergence speed index, electrical conductivity, accelerated aging and enzymatic activity. Six pathogens were found in seeds of soybeans evaluated, namely: Phomopsis sp., Penicillium sp., Aspergillus sp., Fusarium sp., Cercospora kikuchi and Alternaria sp. It was concluded that the sanitary treatment with ozone gas reduces the incidence of these fungi and does not compromise the physiological quality of soybean seeds.
\end{abstract}

Keywords: Glycine $\max ($ L.) Merril, ozone, physiological quality, sanity

\section{Introduction}

Due to the importance that soybean crop has acquired for the Brazilian economy, cultivars with higher yields are increasingly sought. However, intensive cultivation has generated a greater selection pressure of pests and diseases, which make the use of treated seed essential, mainly to ensure the plants survival at the beginning of cycle, once the seeds are characterized as sources of inocula in the diseases spread, caused mostly by fungi.

The fungi occurrence in soybean seeds has been reported in several countries where culture is exploited, being some of them of greater economic importance as, Phomopsis spp., Colletotrichum truncatum, Fusarium spp., Sclerotinia sclerotiorum, Cercospora kikuchii, Aspergillus spp. and Rhizoctonia solani. In addition to these, others have secondary importance and are discovered quite often, as Penicillium spp., Alternaria spp., Chaetomium spp., Cladosporium spp., Curvularia spp., Epicoccum spp., Rhizopus spp.and Nigrospora spp., among others; and their control is basically done with fungicides, via chemical seeds treatment (Conceição et al., 2016; Ferreira et al., 2016; Lee et al., 2015; Zambiazzi et al., 2017).

Widely used, the seeds chemical treatment can cause physiological quality loss, depending on the active principle the dose of the product used and the time between the application of the treatment and the sowing, which leads to the search for alternative treatments that are efficient and with less phytotoxicity. Thus disinfectant processes as a preventive measure can reduce the chemical products use.

In this context, the ozone gas stands out $\left(\mathrm{O}_{3}\right)$, which has proven applicability in the disinfection of hospital environments, food and cooking utensils, due to its high oxidation capacity (Khadre, Yousef, \& Kim, 2001), the gas is also used as micro-organisms and viruses disinfectant, flavor and color removal, and organic matter decomposition (Cataldo, 2008; Karaca \& Velioglu, 2009; Karaca, Velioglu, \& Nas, 2010); in addition to the ecological advantage, as it dismisses the need for handling, storage or chemical containers disposal and by generating oxygen as a product of its degradation, in addition to being able to be produced in the treatment place (Kells, Mason, Maier, \& Woloshuk, 2001; Mendez, Maier, Mason, \& Woloshuk, 2003). 
As agent fungicide, its effectiveness has been proven to effectively control the growth of several fungi in laboratory tests with food (Kottapalli, Wolf-Hall, \& Schwarz, 2005; Scussel et al., 2011; Wu, Doan, \& Cuenca, 2006; B. Zorlugenç, F. K. Zorlugenç, Öztekin, \& Evliya, 2008) and to reduce the contamination of mycotoxins in peanut, figs and chestnuts of Pará, and in field tests with corn contaminated artificially (McDonough et al., 2011; Scussel et al., 2011; Zorlugenç et al., 2008).

However, ozone gas is not universally beneficial, because it can promote changes in chemical constituents in foods, grains and seeds by starch and lipids oxidation and degradation, proteins modifications, grain discoloration and seeds germination loss due to excessive gas use (Tiwari et al., 2010).

Although effective, there are still few studies that prove their efficiency in the seeds treatment, especially those undertaken in sunflower seeds by Rodrigues et al. (2015) and corn (Mylona, Kogkaki, Sulyok, \& Magan, 2014; White, Murphy, Bern, \& van Leeuwen, 2010; White et al., 2013). Therefore, it is necessary to carry out tests to verify the ozone gas effectiveness in the plant pathogens control in other species as well as the changes that may occur on the seeds physiological quality.

In this context, the objective was to evaluate the ozone gas efficiency as a controller agent of plant pathogens and its effect on the physiological quality of soybean seeds.

\section{Material and Methods}

Seeds of two soybean cultivars crop harvested in 2016/2017 (Soybean RR and Soybean Intacta RR2 PRO) were

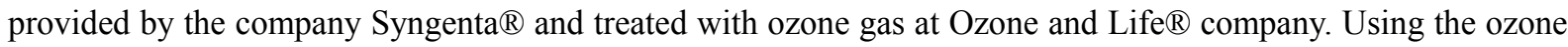
generator, model A and L $35.0 \mathrm{rm}$, the seeds were placed in a continuous flow chamber constructed according to the specifications of Rodrigues et al. (2015) and subjected to five exposure times and two concentrations, as pest control methods. After the treatments the seeds physiological quality was evaluated by the following tests and determinations:

Germination test: 200 seeds of each treatment were sown in germitest paper moistened with 2.5 times the dry substrate weight, made in the form of rolls and maintained in a germinator at $25{ }^{\circ} \mathrm{C}$. The first count was performed at the 5th day after sowing and at the last count at the 8th day. The results were expressed in percentage (MAPA, 2009a).

Tetrazolium test: 200 seeds were pre-moistened in wet paper for 16 hours at $25^{\circ} \mathrm{C}$. For the coloring salt solution of the 2-3-5-triphenyl tetrazolium chloride salt at $0.075 \%$, where the seeds were soaked for $3 \mathrm{~h}$ at $40{ }^{\circ} \mathrm{C}$, in the absence of light. At the end of the coloring period, the solution was discarded and the seeds were washed in tap water and kept submerged until the end of the assessment to prevent over drying. The result of the tetrazolium test was obtained by calculating the mean percentage of viable and vigorous seeds (França Neto et al., 1998)

Accelerated aging: 200 seeds for each treatment were arranged on a screen of aluminum attached to a gerbox. In each gerbox $40 \mathrm{~mL}$ of water were placed and then kept in BOD at $41^{\circ} \mathrm{C}$ for 48 hours (Marcos Filho, 2015). After this period, the seeds were subjected to the germination test with evaluation performed at the 5 th day after sowing, according to methodology described for the germination test.

Seedling emergence: The sowing 200 seeds was performed in sand and soil substrate in the proportion 2:1 and kept in plastic trays. The substrate wetting was performed with a volume of water equal to $70 \%$ of the substrate retention capacity. After sowing the trays were placed in a growth chamber at a temperature of $25{ }^{\circ} \mathrm{C}$ with a photoperiod of 12 hours. The initial stand was evaluated at 7 days, by computing the percentage of normal emerged seedlings. The daily count was also performed until the complete seedlings establishment to determine the emergence speed index (ESI), adapting the formula proposed by Maguire (1962), and also to 14 days the final count was done.

Mass electrical conductivity: four replications of 50 seeds were weighed and then placed in plastic cups containing $75 \mathrm{~mL}$ of deionized water. After 24 hours of imbibition at $25^{\circ} \mathrm{C}$, the electrical conductivity was determined with the aid of a conductivity and the results expressed in $\mu \mathrm{S} \mathrm{cm}^{-1} \mathrm{~g}^{-1}$, according to Vieira (1994).

Sanity test: it was performed by means of the filter paper method (Blotter-Test). For this, the eight replications of 25 seeds each, were placed in Petri dishes containing three sheets of previously moistened germitest paper with a solution of 2,4-dichlorophenoxyacetate potassium (2.4-D) at $5 \mathrm{ppm}$ and agar-agar (1\%). The following plates were incubated for seven days at $20^{\circ} \mathrm{C}$ under a photoperiod of 12 hours. After this period, the evaluation was performed in each seed, being noted all the fungi found, being the identification carried out by means of a stereoscopic microscope (MAPA, 2009b). 
Isoenzymatic analysis: 50 grams of seeds were macerated with antioxidant polyvinylpyrrolidone (PVP) in liquid nitrogen. Subsamples were weighted of $100 \mathrm{mg}$ of macerated material and added with $250 \mu \mathrm{L}$ of extraction buffer $\left(0.2 \mathrm{M}\right.$ Tris $\mathrm{HCl} \mathrm{pH} 8.0+0.1 \%$ of $\beta$-mercaptoethanol). The material was placed in the refrigerator $\left(4{ }^{\circ} \mathrm{C}\right)$ for $12 \mathrm{~h}$ and then centrifuged at $14000 \mathrm{rpm}$ for 30 minutes at $4{ }^{\circ} \mathrm{C}$. The electrophoresis in polyacrylamide gels was developed in discontinuous system (4.5\% concentration gel and $7.5 \%$ in separation gel). The gel/electrode buffer system used was the Tris-glycine $\mathrm{pH}$ 8.9. In order to perform the electrophoretic running, $50 \mu \mathrm{L}$ of supernatant were applied at the gel ducts from each sample and the running held at $4{ }^{\circ} \mathrm{C}$ for four hours at a constant voltage of $150 \mathrm{~V}$. At the end of the race, the gels were revealed to the enzymes malate dehydrogenase $(\mathrm{MDH})$, catalase (CAT), superoxide dismutase (SOD), peroxidase (PO) and isocitrate lyase (ISO), according to protocols contained in Alfenas (2006).

Statistical procedure: the results of each cultivar were analyzed separately by adopting a $5 \times 2$ factorial scheme, in a completely randomized design, being five exposure times $(0,20,40,60$ and 120 minutes) and two ozone gas concentrations $\left(15\right.$ and $25 \mathrm{~g} \mathrm{~m}^{-3}$ ). The data were subjected to analysis of variance by the Scott-Knott test at $5 \%$ probability.

\section{Results}

For the Soybean $R R$, three pathogens were in greater quantity in non-treated seed, being that the fungus Phomopsis sp., Penicillium sp. and Aspergillus sp. Showed an incidence of around $40 \%$. After the ozone action, this value was reduced to values below 10\%, except for Phomopsis sp., which despite of being reduced remained with higher values of incidence (20\%), in relation to the others. The fungi Fusarium sp., Cercospora kikuchi and Alternaria sp, with an average of incidence at around $20 \%$, were also reduced to values below $10 \%$, regardless of the ozone concentration used (Figure 1). 

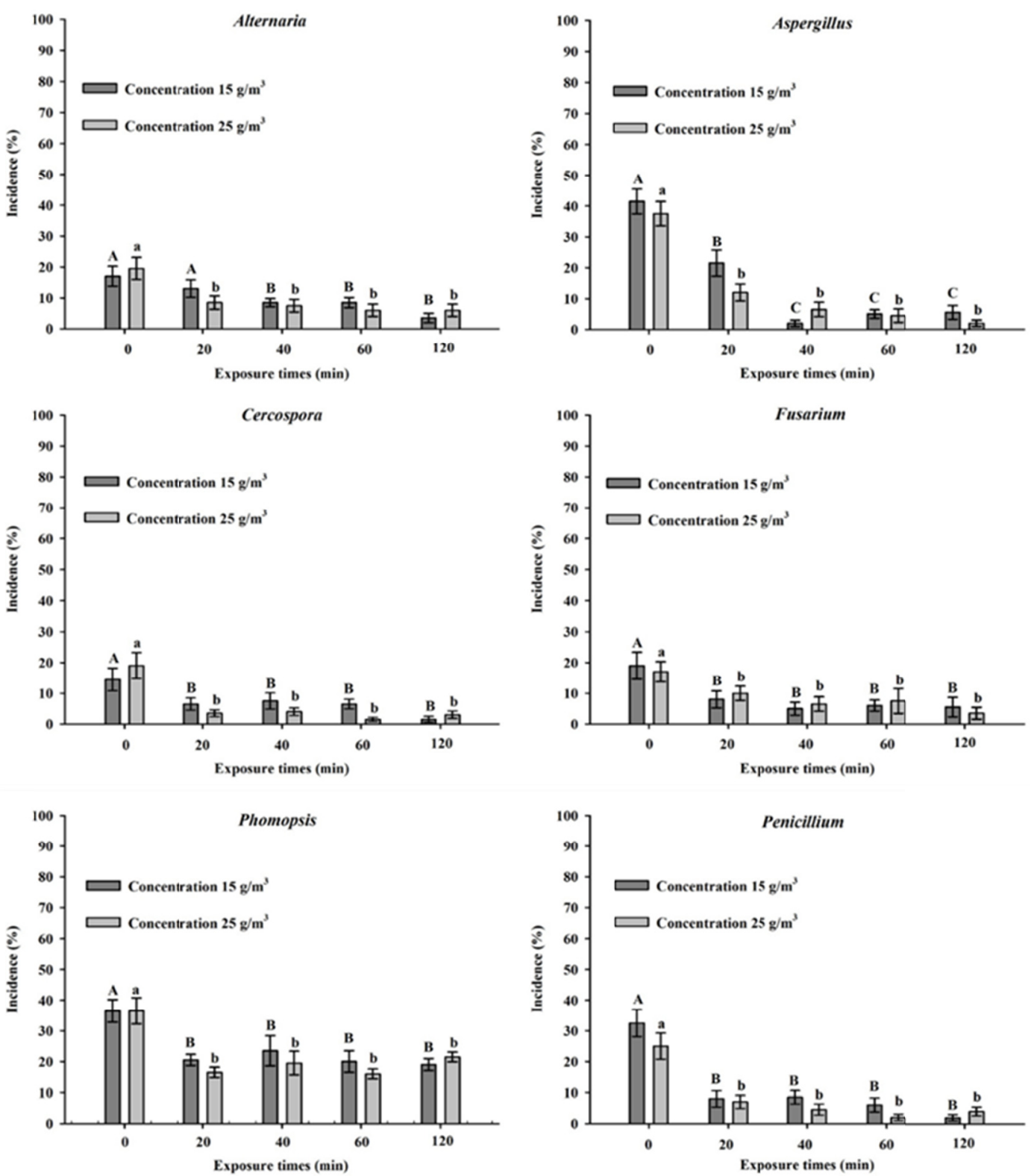

Figure 1. Incidence of fungi present in soybean seeds, Soybean RR, without treatment and treated with ozone gas in two concentrations

Note. Uppercase letters differentiate the concentration $15 \mathrm{~g} / \mathrm{m}^{3}$ and lowercase letters differentiate the concentration $25 \mathrm{~g} / \mathrm{m}^{3}$ at $5 \%$ probability by the Scott-Knott test.

Similar behavior was observed for the cultivar Soybean Intacta RR2 PRO, which had greater impact for the fungus Phomopsis sp. (30\%), Penicillium sp. (30\%) and Aspergillus sp. (40\%), and which were reduced by the ozone action, regardless of the concentration used, as well as other pathogens found (Figure 2).

Similarly, for both cultivars, the ozone gas, regardless of the concentration and exposure time, reduced the incidence of pathogens in soybean seeds in relation to the non-treated ones, however without eliminating them. 

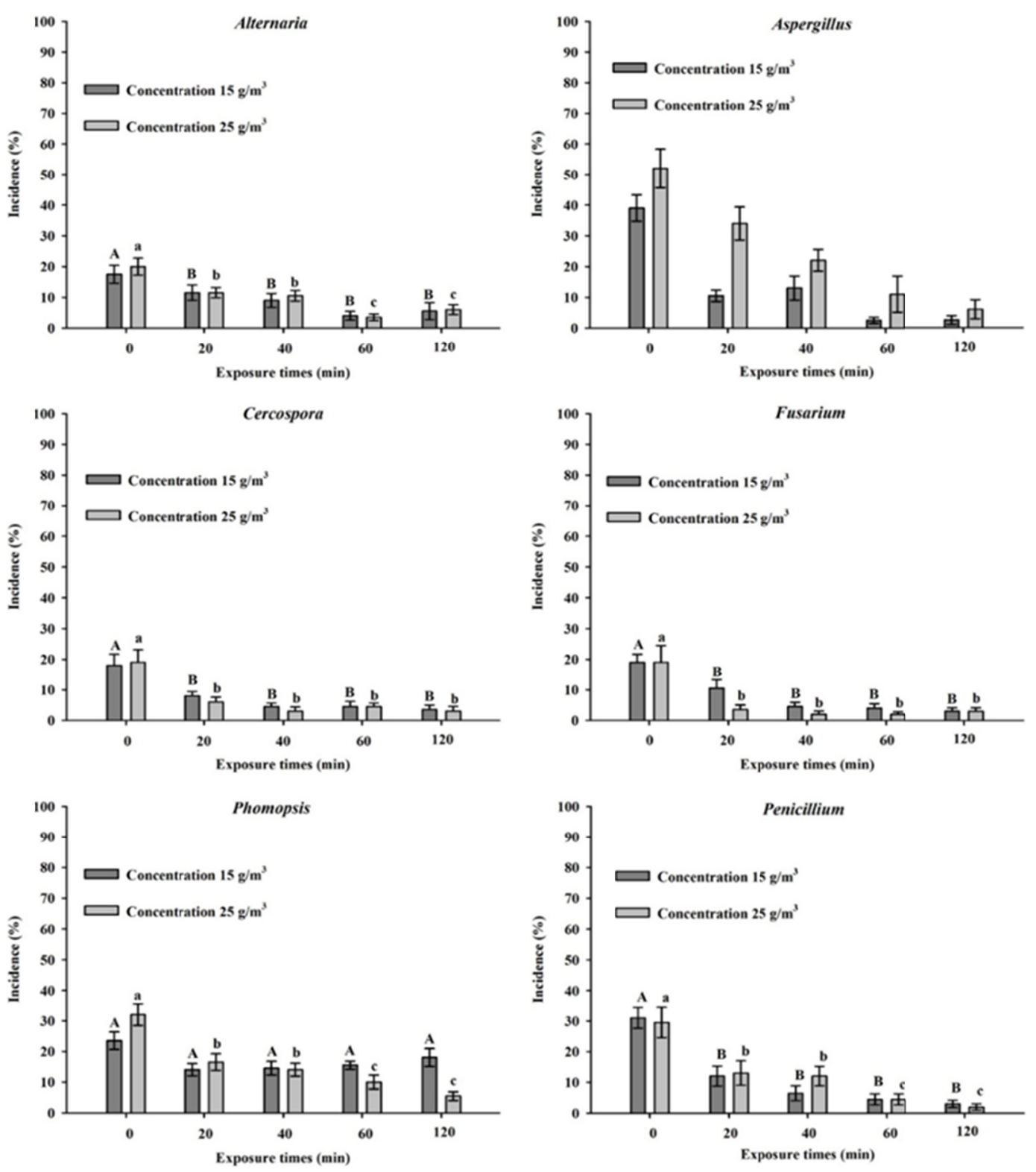

Figure 2. Incidence of fungi present in soybean seeds, cultivar Soybean Intacta RR2 PRO, without treatment and treated with ozone gas in two concentrations

Note. Uppercase letters differentiate the concentration $15 \mathrm{~g} / \mathrm{m}^{3}$ and lowercase letters differentiate the concentration $25 \mathrm{~g} / \mathrm{m}^{3}$ at $5 \%$ probability by the Scott-Knott test.

Regarding the tetrazolium test, the ozone gas did not affect the soybean seeds viability of two cultivars, with results similar to those observed for seeds without treatment (Figure 3). 

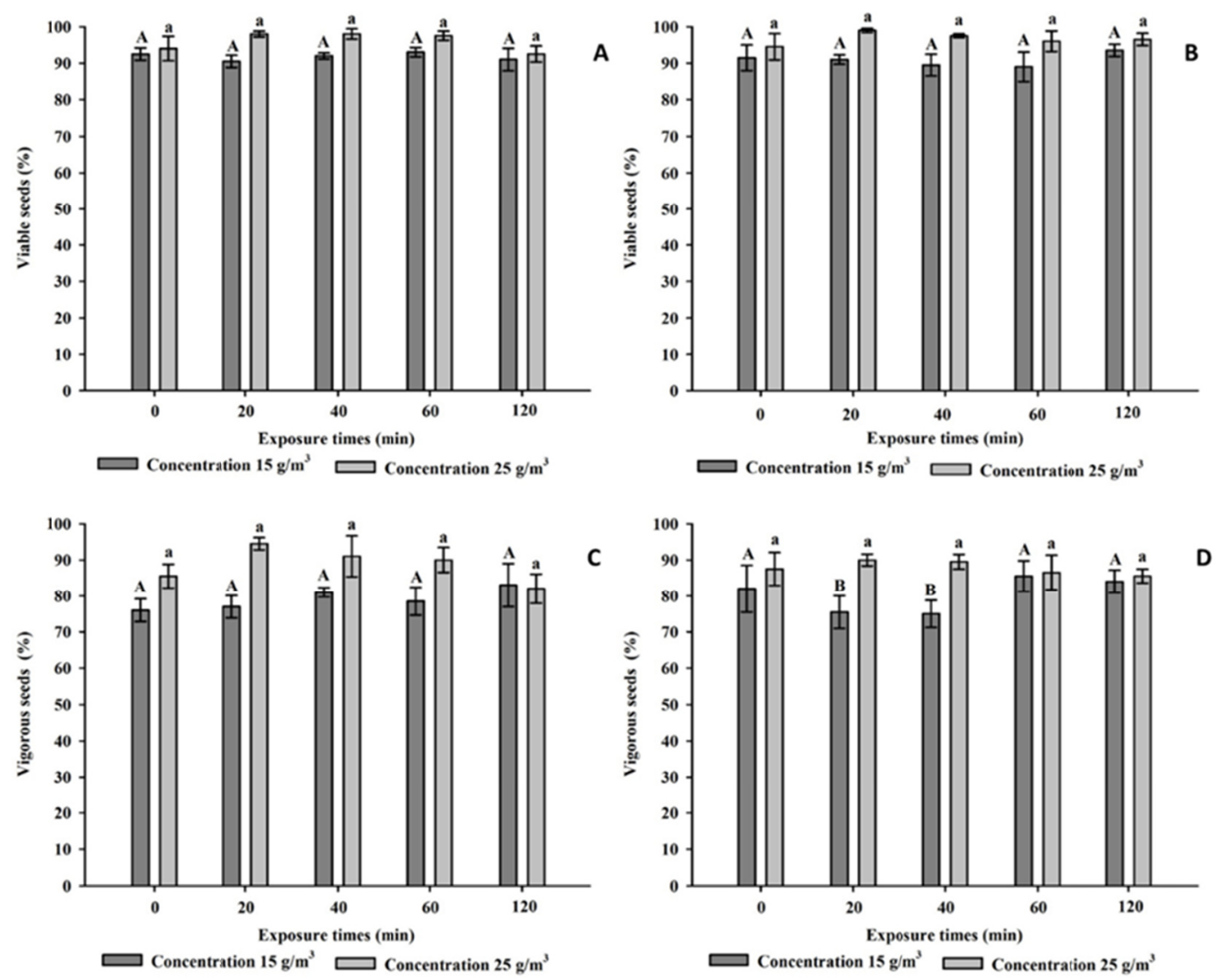

Figure 3. Percentage of viability (Soybean RR - A and Soybean Intacta RR2 PRO - B) and percentage of vigor (Cultivar Soybean $R R-\mathrm{C}$ and Cultivar Soybean Intacta $R R 2 P R O-D$ ) of soybean seeds by the tetrazolium test, of two cultivars treated with ozone gas in two concentrations

Note. Uppercase letters differentiate the concentration $15 \mathrm{~g} \mathrm{~m}^{-3}$ and lowercase letters differentiate the concentration $25 \mathrm{~g} / \mathrm{m}^{3}$ at $5 \%$ probability by the Scott-Knott test.

For both soybean cultivars, it was observed that the seed treatment with ozone did not affect the seeds' vigor, given the results of the first germination count, which maintained an average of $80 \%$ of germination, value on average ten percentage points higher than that observed for the seeds without treatment ( 0 minutes), both for the cultivar Soybean RR (Figure 4A) as to cultivar Soybean Intacta RR2 PRO (Figure 4B) over 120 minutes of exposure. 



Figure 4. First count values (A) and percentage of seeds germination (C) of the cultivar Soybean RR and first count (B) and percentage of seeds germination (D) of the cultivar Soybean Intacta RR2 PRO treated with ozone gas in two concentrations

Note. Uppercase letters differentiate the concentration $15 \mathrm{~g} \mathrm{~m}^{-3}$ and lowercase letters differentiate the concentration $25 \mathrm{~g} \mathrm{~m}^{-3}$ at $5 \%$ probability by the Scott-Knott test.

Counted the germination end, a few changes were observed in the values obtained for the cultivar Soybean RR (Figure 4C) and to cultivar Soybean Intacta RR2 PRO (Figure 4D), whose means remained similar to those observed at the time of the first count, this reinforces that the seeds' vigor has not changed in function of the treatment with ozone gas, regardless of the concentration used.

Still regarding the seeds' vigor, the results obtained in the electrical conductivity and germination test after the seeds' accelerated aging, reinforce what was observed for the soybean seeds germination of two cultivars.

In spite of presenting higher values of electric conductivity, the cultivar 1 (Figure $5 \mathrm{~A}$ ) did not have their values changed as a function of exposure and ozone concentration, the same was observed for the cultivar 2 seeds (Figure 5B). 



Figure 5. Electrical conductivity (A, B) and germination after accelerated aging (C, D) of soybean seeds of two cultivars (cultivar $1 \mathrm{~A}, \mathrm{C}$ and cultivar $2 \mathrm{~B}, \mathrm{D}$ ) treated with ozone gas in two concentrations

Note. Uppercase letters differentiate the concentration $15 \mathrm{~g} \mathrm{~m}^{-3}$ and lowercase letters differentiate the concentration $25 \mathrm{~g} \mathrm{~m}^{-3}$ at $5 \%$ probability by the Scott-Knott test.

The same behavior was observed for the seeds germination subjected to accelerated aging, whose values were little changed in function of the treatment with ozone, regardless of time and concentration used, both for the cultivar 1 (Figure 5C) and to cultivar 2 (Figure 5D).

Similar to what was observed for the other evaluated variables, the treatment with ozone gas in soybean seeds of two cultivars also did not affect the seedling speed and emergence, maintaining the seeds' vigor at similar levels regardless of the exposure time and the concentrations used (Figure 6). 

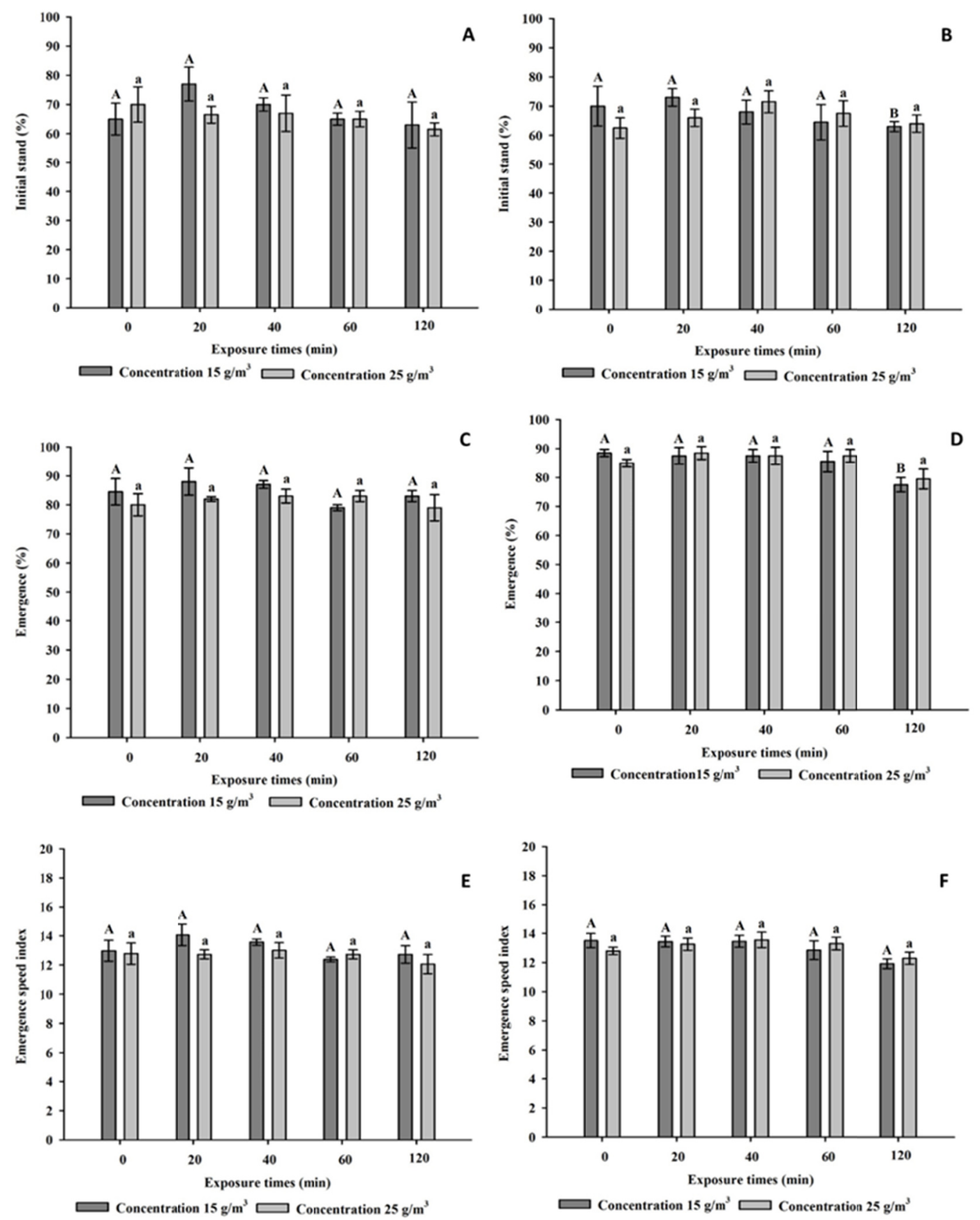

Figure 6. Initial stand, percentage and emergence velocity index of soybean seeds germination of two cultivars

(Cultivar 1-A, C and E; Cultivar 2-B, D and F) treated with ozone gas in two concentrations

Note. Uppercase letters differentiate the concentration $15 \mathrm{~g} \mathrm{~m}^{-3}$ and lowercase letters differentiate the concentration $25 \mathrm{~g} \mathrm{~m}^{-3}$ at $5 \%$ probability by the Scott-Knott test.

For the cultivar Soybean $R R$, there has been change in the enzyme profiles of the Catalase enzyme, when the seeds were exposed for 20 minutes at the lowest concentration, and from 40 minutes in the highest concentration of ozone gas (Figure 7B), to the other enzymes, there were no noticeable changes in the enzyme profiles. 


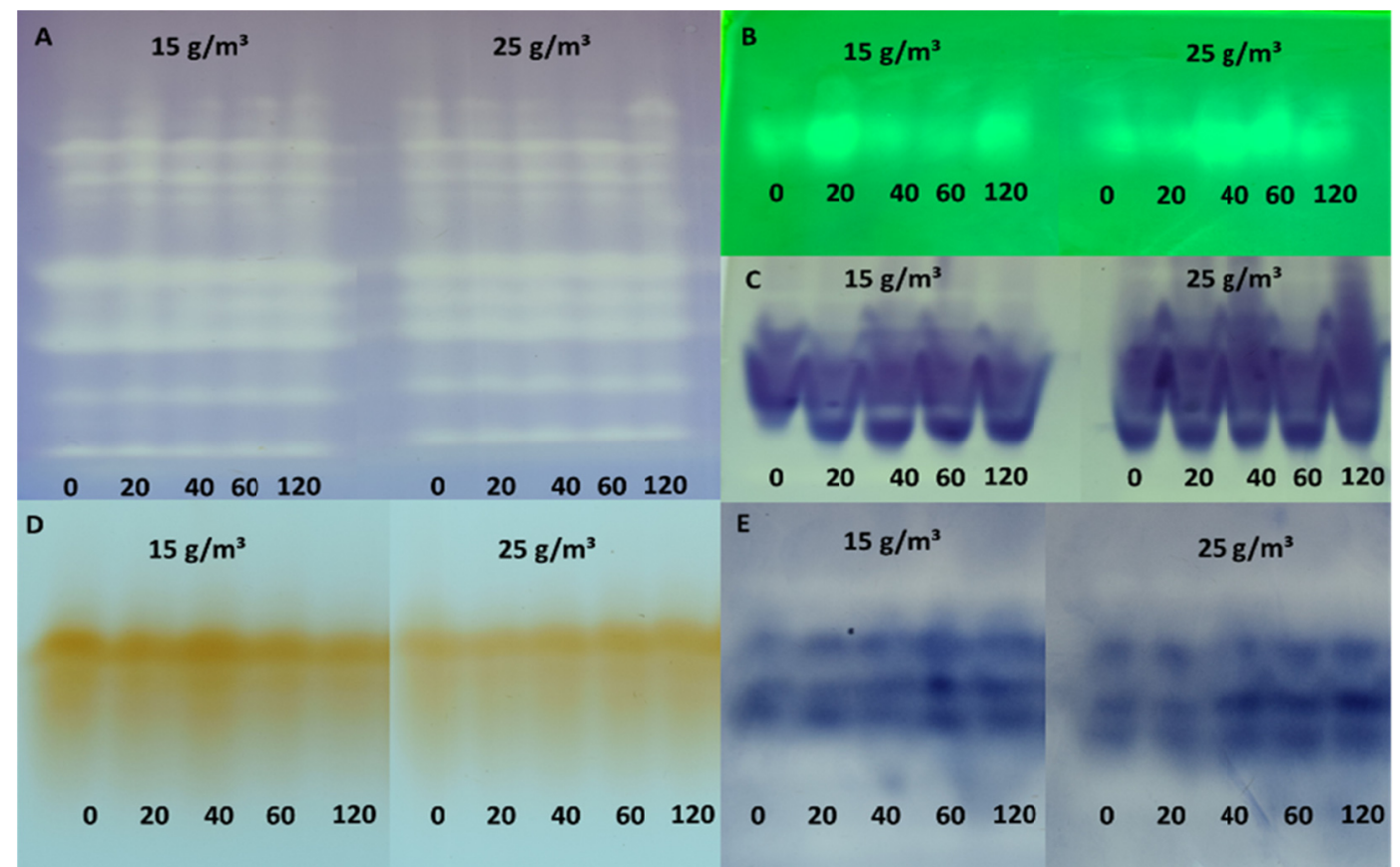

Figure 7. Enzyme profiles of dismutase superoxide (A), Catalase (B), malate dehydrogenase (C), peroxidase (D) and isocitrate lyase (E) extracted from soybean seeds, cultivar Soybean $R R$, treated with ozone gas in two concentrations

Similarly to what was observed for the cultivar Soybean RR, the cultivar Soybean Intacta RR2 PRO showed a change in the catalase enzyme profile when seeds were exposed to higher ozone gas concentrations $\left(25 \mathrm{~g} \mathrm{~m}^{-3}\right)$. Higher activity was observed in seeds without treatment ( 0 minutes) and treated for 20 and 40 minutes (Figure $8 \mathrm{~B})$, and for the other enzymes noticeable changes in the enzyme profiles were not observed.

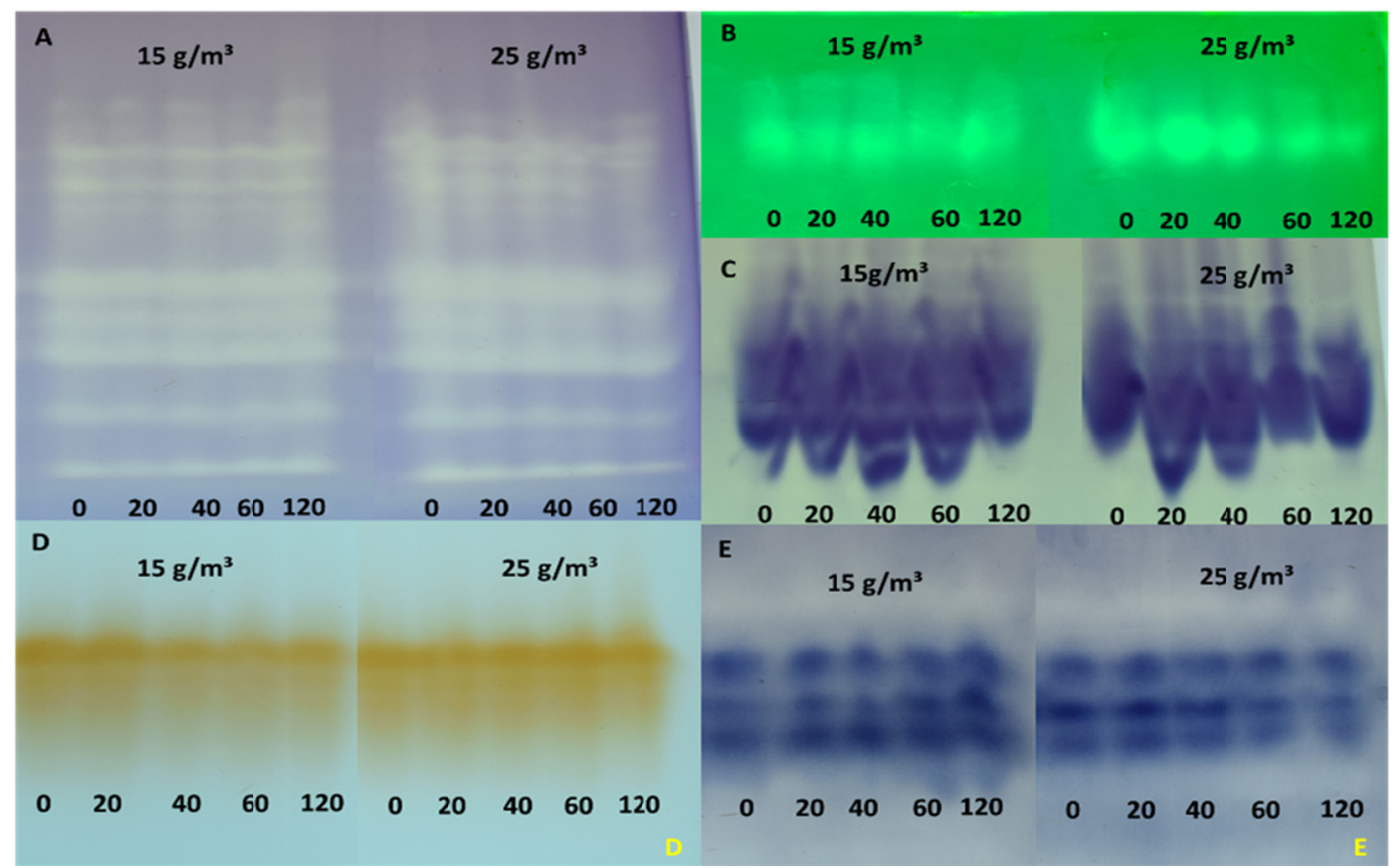

Figure 8. Enzyme profiles of dismutase superoxide (A), Catalase (B), malate dehydrogenase (C), peroxidase (D) and isocitrate lyase (E) extracted from soybean seeds, cultivar Soybean Intacta RR2 PRO, treated with ozone gas in two concentrations 


\section{Discussion}

Despite of being the fungus that showed greater resistance to the ozone effects, Phomopsis spp. is a pathogen that tends to have its quantity of inoculum reduced during seeds storage, both in environmental conditions as well as in controlled temperature and humidity conditions, being that in the later seeds pathogen reduction happens even faster (Carvalho, Novembre, Moraes, \& Gagliardi, 2011; Galli, Panizi, \& Vieira, 2007).

Different authors using chemical treatments with fungicide in soybeans, observed that the products do not eliminate completely the microorganisms presence in the seeds, as the results observed by, Conceição et al. (2014, 2016), Ferreira et al. (2016), Pereira et al. (2011), in a similar manner observed in this study. However, despite this similarity, the use of gas is advantageous due to the ecological gain provided through the use of ozone, which reduces the need for chemical treatment.

Observed the efficiency of different fungicides in the improvement of seeds sanitary quality, some authors associate the action of these products to the potential losses on the seeds physiological quality, resulting in a reduction in the germination, survival and causing seedling abnormalities, such as mesocotyl reduction, leaf fissures, warped and thick leaves; characterizing the phytotoxic effect of the tested products (Abati et al., 2014; Ferreira et al., 2016; Ludwig et al., 2011).

Different from what was observed by the authors, to evaluate different chemical treatments with fungicides, the ozone gas did not negatively affect the physiological quality of soybean seeds of the evaluated cultivars, regardless of the exposure time and concentration used, i.e., no phytotoxic effect was observed, being advantageous when compared to chemical products.

It is know that the seeds pathogens attack affects the seedlings establishment in the field, and unlike that, it was observed a low incidence of fungi present on seeds, after treatment with ozone gas, and also did not affect the speed and percentage of seedling emergence of two evaluated soybeans cultivars, in the same way that the seeds physiological quality was not adversely affected due to oxidation caused by ozone.

The absence of a negative effect on the physiological quality of soybean seeds can be observed by means of results obtained in different tests to which the seeds, of two cultivars were subjected. On the contrary, a slight improvement was observed in physiological quality, possibly due to the pathogens reduction present in the seeds.

From the results obtained it can be inferred that the ozone gas, considered to have high power of oxidation (Karaca et al., 2010; Khadre et al., 2001), the main reason to be used in disinfectant processes (Cataldo, 2008; Karaca \& Velioglu, 2009; Karaca et al., 2010), did not influence the physiological quality of soybean seeds, once that oxidative processes are considered one of the main physiological quality reducer in oilseeds, such as soybean, due to free radicals formation caused by oxidation on cellular tissues and reserve components such as lipids, which are more susceptible to these effects (Oliveira et al., 2016).

Proof that there were no changes caused by oxidation, caused by ozone gas, regardless of the exposure time and of the concentrations used, was given by a few changes in the enzyme profiles extracted from the seeds of both enzymes related to free radicals removal, as for instance catalase (CAT), superoxide dismutase (SOD) and Peroxidade (PO), as well as those involved in respiratory processes-Malate dehydrogenase (MDH) and reserves mobilization (isocitrate lyase-ISO).

Despite its effectiveness in reducing the incidence of the majority of fungi in soybean seeds, it was observed that the species Phomopsis sp. Has a greater capacity for resistance to the ozone disinfectant action, because its reduction provided by the treatments does not resemble other observed fungi species, which had their incidence rates reduced more sharply. Thus, further studies should be conducted in order to assess whether higher concentrations or exposure times to ozone will be able to reduce or eliminate, more efficiently, the incidence of Phomopsis sp. In soybean seeds or other agricultural crops, without compromising the seeds physiological quality.

Corroborating with other authors, the ozone gas has the potential to be used in the plant pathogens control, not only in the environments disinfestation, water treatment and in the food sterilization, as well as the soybean seeds treatment, as well as other cultures of agricultural importance, as highlighted by Rodrigues et al. (2015) upon evaluating the ozone potential in the sunflower seeds and corn seeds treatment (White et al., 2010, 2013), which did not have their physiological quality negatively affected when the ozone gas was used in the microorganisms control present in the seeds. 


\section{Conclusions}

Treatment with ozone gas concentration of $15 \mathrm{~g} \mathrm{~m}^{3}$ per 20 minutes reduces the incidence of Alternaria, Aspergillus, Cercospora, Fusarium, Penicillium and Phomopsis fundi in soybean seeds.

Ozone up to $25 \mathrm{~g} \mathrm{~m}^{3}$ does not affect the physiological quality in expositions per periods up to 60 minutes, for cultivar Soybean Intacta RR2 PRO, and up to 120 minutes for cultivar Soybean RR.

The use of ozone did not negatively affect the biochemical quality of soybean seeds.

\section{References}

Abati, J., Zucareli, C., Foloni, J. S. S., Henning, F. A., Brzezinski, C. R., \& Henning, A. A. (2014). Treatment with fungicides and insecticides on the physiological quality and health of wheat seeds. Journal of Seed Science, 36(4), 392-398. https://doi.org/10.1590/2317-1545v36n41006

Alfenas, A. C. (2006). Eletroforese e marcadores bioquímicos em plantas e microorganismos (2nd ed.). Viçosa: Ed. UFV.

Carvalho, T. C., Novembre, A. D. L. C., Moraes, M. H. D., \& Gagliardi, B. (2011). Envelhecimento acelerado e ocorrência de fungos em duas cultivares de soja. Semina: Ciências Agrárias, 32(1), 165-172. https://doi.org/10.5433/1679-0359.2011v32n1p165

Cataldo, F. (2008). Ozone decomposition of patulin-A micotoxin and food contaminant. Ozone: Science and Engineering, 30(3), 197-201. https://doi.org/10.1080/01919510801925930

Conceição, G. M., Barbieri, A. P. P., Lúcio, A. D., Martin, T. N., Mertz, L. M., Mattioni, N. M., \& Lorentz, L. H. (2014). Desempenho de plântulas e produtividade de soja submetida a diferentes tratamentos qumicos nas sementes. Bioscience Journal, 30(6), 1711-1720.

Conceição, G. M., Lúcio, A. D., Mertz-Henning, L. M., Henning, F. A., Beche, M., \& Andrade, F. F. (2016). Physiological and sanitary quality of soybean seeds under different chemical treatments during storage. Revista Brasileira de Engenharia Agricola e Ambiental, 20(11), 1020-1024. https://doi.org/10.1590/ 1807-1929/agriambi.v20n11p1020-1024

Ferreira, T. F., Oliveira, J. A., Carvalho, R. A. de, Resende, L. S., Lopes, C. G. M., \& Ferreira, V. de F. (2016). Quality of soybean seeds treated with fungicides and insecticides before and after storage. Journal of Seed Science, 38(4), 278-286. https://doi.org/10.1590/2317-1545v38n4161760

França Neto, J. B., Kryzanowski, F. C., \& Silva, W. R. (1998). O teste de tetrazólio em sementes de soja (p. 72). Londrina: Embrapa CNPSo.

Galli, J. A., Panizi, R. de C., \& Vieira, R. D. (2007). Sobrevivência de patógenos associados a sementes de soja armazenadas durante seis meses. Revista Brasileira de Sementes, 29(2), 205-213. https://doi.org/10.1590/ S0101-31222007000200027

Karaca, H., \& Velioglu, Y. (2009). Effects of some metals and chelating agents on patulin degradation by ozone. Ozone: Science and Engineering, 31(3), 224-231. https://doi.org/10.1080/01919510902766662

Karaca, H., Velioglu, Y. S., \& Nas, S. (2010). Mycotoxins: Contamination of dried fruits and degradation by ozone. Toxin Reviews, 29(2), 51-59. https://doi.org/10.3109/15569543.2010.485714

Kells, S. A., Mason, L. J., Maier, D. E., \& Woloshuk, C. P. (2001). Efficacy and fumigation characteristics of ozone in stored maize. Journal of Stored Products Research, 37(4), 371-382. https://doi.org/10.1016/S0022 $-474 \mathrm{X}(00) 00040-0$

Khadre, M. A., Yousef, A. E., \& Kim, J. G. (2001). Microbiological aspects of ozone applications in food: A review. Journal of Food Science, 66(9), 1242-1252. https://doi.org/10.1111/j.1365-2621.2001.tb15196.x

Kottapalli, B., Wolf-Hall, C. E., \& Schwarz, P. (2005). Evaluation of gaseous ozone and hydrogen peroxide treatments for reducing Fusarium survival in malting barley. Journal of Food Protection, 68(6), 1236-1240. https://doi.org/10.4315/0362-028X-68.6.1236

Lee, J. H., Hwang, S. R., Lee, Y. H., Kim, K., Cho, K. M., \& Lee, Y. B. (2015). Changes occurring in compositions and antioxidant properties of healthy soybean seeds [Glycine max (L.) Merr.] and soybean seeds diseased by Phomopsis longicolla and Cercospora kikuchii fungal pathogens. Food Chemistry, 185(15), 205-211. https://doi.org/10.1016/j.foodchem.2015.03.139

Ludwig, M. P., Lucca Filho, O. A., Baudet, L., Dutra, L. M. C., Avelar, S. A. G., \& Crizel, R. L. (2011). Seed quality of stored soybean after coating with amino acid, polymer, fungicide and insecticide. Revista 
Brasileira de Sementes, 33(3), 395-406. https://doi.org/10.1590/S0101-31222011000300002

Maguire, J. D. (1962). Speed of germination - aid in selection and evaluation for seedling emergence and vigor. Crop Science, 2, 176-177. https://doi.org/10.2135/cropsci1962.0011183X000200020033x

MAPA (Ministério da Agricultura Pecuária e Abastecimento). (2009a). Manual de Análise Sanitária de Sementes (p. 200). Brasília: MAPA-ACS.

MAPA (Ministério da Agricultura Pecuária e Abastecimento). (2009b). Regras para análise de sementes (p. 395). Secretaria de Defesa Agropecuária. Brasília: MAPA/ACS.

Marcos Filho, J. (2015). Seed vigor testing: An overview of the past, present and future perspective. Scientia Agricola, 72(4), 363-374. https://doi.org/10.1590/0103-9016-2015-0007

McDonough, M. X., Campabadal, C. A., Mason, L. J., Maier, D. E., Denvir, A., \& Woloshuk, C. (2011). Ozone application in a modified screw conveyor to treat grain for insect pests, fungal contaminants, and mycotoxins. Journal of Stored Products Research, 47(3), 249-254. https://doi.org/10.1016/j.jspr.2011.04. 001

Mendez, F., Maier, D., Mason, L., \& Woloshuk, C. (2003). Penetration of ozone into columns of stored grains and effects on chemical composition and processing performance. Journal of Stored Products Research, 39(1), 33-44. https://doi.org/10.1016/S0022-474X(02)00015-2

Mylona, K., Kogkaki, E., Sulyok, M., \& Magan, N. (2014). Efficacy of gaseous ozone treatment on spore germination, growth and fumonisin production by Fusarium verticillioides in vitro and in situ in maize. Journal of Stored Products Research, 59, 178-184. https://doi.org/10.1016/j.jspr.2014.08.001

Oliveira, A. S., Carvalho, M. L. M., Bárbara, C. N. V., Guimarães, R. M., Oliveira, J. A., \& Pereira, D. S. (2016). Biochemical changes in fiber naturally colored cottonseeds during storage. Journal of Seed Science, 38(2), 101-109. https://doi.org/10.1590/2317-1545v38n2156374

Pereira, C. E., Oliveira, J. A., Guimares, R. M., Vieira, A. R., Evangelista, J. R. E., \& Oliveira, G. E. (2011). Tratamento fungicida e peliculização de sementes de Soja submetidas ao armazenamento. Ciencia e Agrotecnologia, 35(1), 158-164. https://doi.org/10.1590/S1413-70542011000100020

Rodrigues, V. O., Costa, F. R., Nery, M. C., Cruz, S. M., Melo, S. G. F. de, \& Carvalho, M. L. M. de. (2015). Treating sunflower seeds subjected to ozonization. Journal of Seed Science, 37(3), 202-210. https://doi.org/10.1590/2317-1545v37n3148582

Scussel, V. M., Giordano, B. N., Simao, V., Manfio, D., Galvao, S., \& Rodrigues, M. N. F. (2011). Effect of Oxygen-Reducing Atmospheres on the Safety of Packaged Shelled Brazil Nuts during Storage. International Journal of Analytical Chemistry, 2011, 1-9. https://doi.org/10.1155/2011/813591

Tiwari, B. K., Brennan, C. S., Curran, T., Gallagher, E., Cullen, P. J., \& O’Donnell, C. P. (2010). Application of ozone in grain processing. Journal of Cereal Science, 51(3), 248-255. https://doi.org/10.1016/j.jcs.2010. 01.007

White, S. D., Murphy, P. T., Bern, C. J., \& van Leeuwen, J. H. (2010). Controlling deterioration of high-moisture maize with ozone treatment. Journal of Stored Products Research, 46(1), 7-12. https://doi.org/10.1016/ j.jspr.2009.07.002

White, S. D., Murphy, P. T., Leandro, L. F., Bern, C. J., Beattie, S. E., \& van Leeuwen, J. H. (2013). Mycoflora of high-moisture maize treated with ozone. Journal of Stored Products Research, 55, 84-89. https://doi.org/ 10.1016/j.jspr.2013.08.006

Wu, J., Doan, H., \& Cuenca, M. A. (2006). Investigation of gaseous ozone as an anti-fungal fumigant for stored wheat. Journal of Chemical Technology and Biotechnology. https://doi.org/10.1002/jctb.1550

Zambiazzi, E. V., Bruzi, A. T., Zuffo, A. M., Soares, I. O., Mendes, A. E. S., Teresani, A. L. R., ... Moreira, S. G. (2017). Desempenho agronómico e qualidade sanitária de sementes de soja em resposta à adubação potássica. Revista de Ciências Agrárias, 40(3), 543-553. https://doi.org/10.19084/RCA16055

Zorlugenç, B., Zorlugenç, F. K., Öztekin, S., \& Evliya, I. B. (2008). The influence of gaseous ozone and ozonated water on microbial flora and degradation of aflatoxin B1 in dried figs. Food and Chemical Toxicology, 46(12), 3593-3597. https://doi.org/10.1016/j.fct.2008.09.003 


\section{Copyrights}

Copyright for this article is retained by the author(s), with first publication rights granted to the journal.

This is an open-access article distributed under the terms and conditions of the Creative Commons Attribution license (http://creativecommons.org/licenses/by/4.0/). 